\title{
The Importance of Insurance Premium Payment Moment, One of the Key Elements of Insurance Contract and the Respective Problematic
}

\author{
Dr. Juliana Bylykbashi
}

\begin{abstract}
The goal of this paperwork refers to civil specific legal insurance relationships, like premium payment. The motive to deal with this aspect comes because of various doctrinal interpretations and especially because of some legal situations which present problematics in its definition according to Albanian civil legislation which provides insurance contract and its interpretations encountered during the Albanian judicial practice. The questions coming up dealing this issue are: Depending on premium payment moment, how is the insurance contract classified, as a consensual or a real one? On the other side, depending on the answer of the first question, when an insurance contract is considered valid: when the deal is concluded or once the premium is paid? And in the end, according to the answers of the aforementioned questions, there comes an important issue, the one of determining the time when the insurer responsibility starts toward the insured, regarding the contract conclusion, as provided in Article 1124 of the Civil Code of Republic of Albania, or premium payment, either partial or full premium payment, which is the principal reasons that precedes the initial of insurer's responsibility. This paperwork is basically relied on doctrinal interpretations regarding the abovementioned questions, the interpretation of Albanian Courts of Articles 1124 and 1125 of the Civil Code of Republic of Albania, and on courts decision upon these issues.
\end{abstract}

Keywords: The Importance of Insurance Premium Payment Moment, One of the Key Elements of Insurance Contract and the Respective Problematic

\section{Introduction}

The insurance contract is a very important contractual relationship in civil circulation. Considering that human society always tends towards prosperity, to the economic growth and development of the country and along with people needs to transfer risk from various cases (or calamities), the insurance contract is constantly having more active and executive space in Albania. We encounter this development either quantitavely (the constant growing number of citizens voluntarily addressed to this institution) or qualitatively like introducing on market of insuring mediator who insures the best possible terms for insurance contract, and the best protection for consumer and policeholder.

In the history of legal arrangement of insurance contract, actually in Albania, the arrangement through legal provisions of this contract dates early, since the time of Albanian state birth, but the first time of legal arrangement of this relationship was done on approval of the Albanian trade Code in 19321. During the years after the Second World War the insurance contract in Albania was arranged by Law no. 2359 of year 1956 "On legal actions and liabilities"2, which arranges among others the insurance contract as well, its conclusion, the object, the subjects and rights and obligations of contractual parties, and many other significant aspects. This is a very important law inter alia the actual civil legislation ${ }^{4}$ has transposed almost the same provisions which refer to the insurance contract arrangement, despite the amendments of such legislation over the years for various eras. We find the insurance contractual relationship even in the Civil Code of 1981, regardless

\footnotetext{
${ }_{1}^{1}$ The trade Code dates in 1932, published in the Official Gazette of March $5^{\text {th }}$, 1932. Its compilation was stimulated from need to arrange trade companies' activity especially of Italian companies, which dominated in Albania. For more information: A.Luarasi, mentioned work, pg. $405-406$

${ }^{2}$ Provisions of the above mentioned law cited "de jure" the increase of the role of legal actions in relationships between persons, but as shown in later practices in Albania "de facto" their role was limited to the maximum as a result of acting in current political-economical background.
} 
the shortening of such contract because of time circumstances. ${ }^{1}$ The importance of insurance contract can also be seen from specific arrangement this contract has in the Albanian civil legislation. The legal norms arranging the insurance contract in Albania have submitted a great development even through legal amendments done through various changes. In legal providing of insurances we mention the Civil Code of Republic of Albania of year 1994 (actually in force) to the insurance contract provision. In addition, the concept of insurances, their provision, insuring by insurance companies, the interior legal organization of such companies, as trade companies in form of shareholding companies, the insurance concept and that of re-insurance, and the mediation are object of arrangement of the Law no. 52, date 22. 05. 2014 "For the Insurance and Re-Insurance Activity" of year 2014. Meanwhile, a special attention the legislation pays to the obligatory insurance in transport sector", of year 2009. As it seems, the legal arranging framework is so wide, and it shows the importance of insurance contract and insurance activity.

Notwithstanding, to argue this paperwork I am specifically stopping on some of provisions of XXIII Chapter of the Civil Code of Republic of Albania, related to the insurance contract arrangement. The insurance Contract differs in many issues from the other sorts of typical contracts provided by this Code. Just because of their very special sort, often a lot of various problems have been raised in practice needing the legal interpretation of provisions in this Code, by Albanian Courts.

The Insurance Contract, by the Civil Code of Republic of Albania is a special and distinctive contract from all the other typical contracts because its object is "delegation of responsibility for damage reward". ${ }^{2}$ This means that the insurer through the insurance contract is obliged to indemnify the damage submitted by the insured for his person/or property. This insurance consists also to the return of an approximate damaged cash value. ${ }^{3}$

In material sense through civil legal relationship of insurance one party transfers to the other party the damage risk, which is the obligation for reward of a damage, in case it happens, despite this damage has not been caused because of the second party. ${ }^{4}$

If we deal with the legal nature of insurance contract according to the legal provisions, the insurance contract as a bilateral legal action is distinguished by the reciprocity of obligation of the parties to one another. Moreover, the insurance contract is a term contract, which consists in time when this contract brings legal consequences, time when the insurance premium has to be paid to the insurend and time when the insurance reward must be paid by the insurer. ${ }^{5}$

According to the definition of insurance contract given by Article 1113 of the Civil Code of Republic of Albania, through this contract, one party the insurer, if the circumstances provided by the contract are proved, which is the insurance case, undertakes to pay to the other party, to the insured or to a third person, when the insurance contract is entered in benefit of a third person, a cash reward within the amount provided by this contract, according to a premium paid by the insured. From this definition we issue another characteristic of the insurance contract, as a conditional contract ${ }^{6}$ on suspensive condition when the rights and obligations are raised in case the case happens. ${ }^{7}$

The goal of analyzing some of the insurance contract characteristics specifically serves to dealing one of the most key elements of insurance contract, to the insurance premium and to its paying moment. Like it results from the Civil Code of Republic of Albania, the insurance contract is a formal contract, a solemn one, so the shape must be for the effect of ad

\footnotetext{
${ }^{1}$ The code of year 1981 arranged only the property insurance contract, and it has no provisions or paragraph about legal arrangement of person's insurance contract, which really consisted to a very big shortcoming of this Code. The basic principle of arranging such civil legal relationships of that time was the centralization principle, the lack of using class and the elimination of private property.
}

\footnotetext{
2 Skrame Olti, Commentary of the Civil Code of Republic of Albania, the second volume, edition of Onufri, 2011, pg. 655

3 Tutulani-Semini Mariana, The law of Obligations and Contracts, Special Part, Tirana, 2006, Pg. 171

4 Ibidem,

${ }^{5}$ Nuni A,Mustafaj,I.Vokshi A, The right of liabilities II", Tirana, 2008.

${ }^{6}$ In article 84 of the Albanian Civil Code it is established that: "The legal transaction is conditioned when the derivation of extinguishment of rights and obligations foreseen in it depends on the event which is not known if it would happen."

7 The Albanian civil code recognizes 2 types of conditions, the suspending one and the resolving one. When the condition is supensive the legal action does not bring the consequences wished by the parties. The rights and obligations provided by the conditional legal action are related to the condition, the party who has the rights cannot submit any request to the obligated party. In addition, the obligated party cannot affect or threaten the loss of the other party's right because if the event is proved, it has to reward the damage to the other party.
} 
substantiam, which is in written through the insurance policy or proof ${ }^{1}$. From literal analysis and interpretation of definition given by the Civil Code in its Article 1113 it is clear that the insurer "... will undertake to pay to the other party .... reward in cash, only against a premium paid by the insured" This means that the premium payment is an essential condition of the insured which enables the execution of insurance contract by the insurer, so the cover that the last one will undertake to make to the insured in case of proving one of the insurance events. In the interpretation a contrario this means that not paying the premium by the insured, does not bring any legal consequences for the insurer, no contract obligation for him, so we conclude that not paying the premium releases the insurer from the responsibility to reward the insured, which means that we are not in a contract any more. If we had an effective contract there would be legal consequences for the parties, but in this case we do not have any legal consequences. Nevertheless, the above mentioned provisions are inseparable from articles 1124 and 1125 of the Civil Code of Republic of Albania.

The question coming from the interpretation of these provisions is related to the moment of entering in force of the insurance contract and as a result to the insurer's responsibility. On one side, paying the premium is an essential condition for the existence of the insurance contract or is its payment one of the main obligations of the insured, which comes from already existent insurance contract?

The issue of insurance premium is one of the main and significant points in insurance issues because paying the insurance premium corresponds exactly to the provision of insurer of the insured risk worth. The insurance premium is the risk price preptium periculi. Not paying the insurance premium, in some cases can bring the release of insurer from the obligation to cover the insurance in case the insured event is proved. This is also one of the main and the most important obligations of the policeholders. ${ }^{2}$ On the other side, one of the characteristics which distinguishes the insurance contract from the other typical contracts according to the Civil Code of Republic of Albania is the special moment when this contract enters in force. According to the Civil Code of Republic of Albania, the insurance Contract enters in force at $240^{\prime}$ clock of the day when the contract is concluded. ${ }^{3}$ In relation with this provision I also refer to the relevant article of the Civil Code which provides that not paying the premium or the first installment on term ${ }^{4}$ entails the suspension of the insurance contract, till at $24 \mathrm{o}^{\prime}$ clock of the day when the insured pays the amount he owes to. ${ }^{5}$ (Considering these two viewpoints compared to one another it seems that we have two various provisions or better say two provisions conceptually not clear, something that takes to their various interpretations and there are problems during their enforcement in practice when the parties, the insured can pretend the insurance cover by one side, because of a contract entered with the insurer, but on the other side the insurer does not meet their request because of the contract suspensions, which comes because of not paying the premium. If we would take a hypothetical case, if the insurance event happens because the contract between the parties is engaged between $160^{\prime}$ clock of making contract and 24 of the moment when the contract enteres in force, would we be in conditions where the insurer must indemnify the insured? Therefore, it is important to determine the moment when the insurance contract enters in force.

According to the above mentioned legal provisions, it comes up that the contract enters in force at 24 of the day after the contract conclusion, therefore the parties have the rights and liabilities beginig at this moment, but on the other side the contract is suspended till at 24 of insurance premimum payment or of its first installment. So, in case the parties enter in this insurance contract, but the insured does not pay the premium, then we do not have a contract, for as long as there are no rights and obligations between them. It would be more right, to express directly that the insurance contract enters in force only after paying the insurance premium, so at 24 of the day when the premium is paid. This because we have double doubts in the Civil Code for the same object of arrangement, but expressed in various ways and meanings. On one side it is explicitely expressed that the insurance contract enters in force at 24 of the day of contract conclusion, but on the other side it comes that the contract does not enter in force, because the rights and obligations of the parties, which essentially are the reason for which the parties enters in legal relationship of obligation, are suspended till at 24 of paying the premium.

If referred to article 1125 as a moment of effectively entering in force, then the contract is considered entered at this moment and the provision in article 1124 can be considered as a form of "preliminary contract", which are contracts object of which

\footnotetext{
${ }^{1}$ Article 1114 of the Civil Code of Republic of Albania,1994.

2 Luik Olavi-Jüri, Kontautas Tomas, Current Issues of Business and Law, 2012.

${ }^{3}$ See, the first paragraph of Article 1124 of the Civil Code of Republic of Albania

4 Paying the premium can be unique or periodic. If unique it has to be totally paid in advance, if periodically it has

to be paid within the terms established in policy.

${ }^{5}$ See, the first paragraph, the second sentence of Article 1125 of the Civil Code of Republic of Albania.
} 
is entering in contract in the future, and not an insurance contract, except the case when the insured pays the insurance premium since at the moment of entering in contract according to Article 1124, but regarding entering in force, anew we have the arrangement of (Article 1125, entrance in force of contract at 24 of premium payment.

On the other side, in interpretation of abovementioned provisions, if we consider the insurance contract enters in force according to article 1124, so at 24 after the contract is concluded, then we conclude that the insurance contract is a consensual one, which enters in force after reaching the deal between the contract parties, without the need that one party gives or consign a certain object. So, the parties are considered to be in legal obligation relationships, enjoying the relevant and mutual rights and obligations. According to this interpretation, this means that in an hypothetical case if two subjects enter in an insurance contract, the insuring company issues the insurance policy, and according to the Civil Code, since at this moment this contract is considered valid, but the insured does not pay the premium, then considering that the insurance contract is a consensual contract according to Article 1124 of the Civil Code, the insured despite not paying the insurance premium, he has the right to pretend and profit from damage cover, if this damage or risk is proved to happen after 24 of entering in this contract.

But in no practical cases it does not happen so, except if the parties have agreed on this way of reward, something very difficult, considering that the main goal of insurance companies, as trade companies is profit realization.

Nevertheless, in continue of interpretation of the two above mentioned provisions we take the other overview, that of the insurance contract consideration as a real one, which enters in force not at the moment when the deal is reached between the contract parties, but one of the parties is indispensably to give or consign a certain object to be considered entered in force. Only at this moment, the parties have their relative and mutual rights and obligations otherwise we do not have any more legal relationships of obligation between the subjects. So paying the premium is a condition sine qua non of existence of this contract.

As such, it enters in force only after the insured pays the insurance premium, regardless the fact when pays it, once after the deal, the conclusion of contract and issuance of insurance policy or after this moment, always in respect of terms established in the Civil Code and in the Contract between the parties. Otherwise, which would be the goal that the legislation offers for an insurance contract existence according to Article 11241, (a contract without legal power, for as long as it remains such by Article 1125 and the possibility this contract has to produce any legal consequences, desired by the parties. I think that, the goal of legislator could have been only this, like ut supra interpreted. Otherwise, if we considered the insurance contract a consensual one, then the fact that the insurer is right not to meet his contractual obligation according to Article 1125, because the insurance premium has not been paid by the insured would be considered legitimated by the legislator as one of the cases of non-execution of contractual obligation by one party, because the other party has not met the obligation reciprocally, something that would confront with the general law principles, and especially with the liabilities law principles.

According to these principles, the creditor and debtor must behave correctly, unbiasly and according to reasonable requirements ${ }^{2}$ of other principle showing the necessary care and bein accurate in meeting the obligation. ${ }^{3}$ The creditor, in our case the insurer, in no case can avoid fulfilling his obligation through reasoning that the debtor has not executed the contractual obligations. Otherwise, he must continue realizing his obligations, according to the conditions established in the Civil Code and in the contract, and the effects of non-execution are specifically arranged by the Civil Code, where in such cases the right is conferred by the creditor's right to pretend a damage reward in case of non-execution or delayed execution of the obligation by debtor. ${ }^{4}$ Therefore, considering all these principles, the only reason why it is provided in this way in Article 1125, when the contract "is suspended" which is the insurer does not cover the insurance case up to the moment of paying the premium, we conclude that the insurance contract can be a real contract. According to another author of law,

\footnotetext{
${ }^{1}$ We must say that article 1124 finds the execution only for the property insurance contract, because according to the fourth paragraph of the same article it does not apply for the life insurance contract.

${ }^{2}$ Article 422 of the Civil Code of Republic of Albania, 1994.

${ }^{3}$ Article 455 of the Civil Code of Republic of Albania, 1994.

${ }^{4}$ Article 476 and followings of the Civil Code of Republic of Albania, 1994.
} 
the insurance contract is a formal and real contract, which is considered engegaged only after the insured pays to insurance premium to the insurer. ${ }^{1}$

If we analized legal provisions on consensual and real actions, the real legal actions are the legal ones which require not only the expression of will, but even the consignment of object, that is the object of legal action. We have to distinguish the fact when the consignment of object is done on goal of execution in a consensual legal act because in this case, the object consignment is made for the effect of obligation execution. Therefore the object consignment does not transfer the legal act to real legal act ${ }^{2}$. In the real legal act the consignment of object is necessary for its validity which makes this qualify.

The abovementioned discussion does not remain only in the aspect of a simply doctrinal debate, but of great importance in practice. This because, both provisions can be used interpreted by both parties in a judicial proceeding, where one expresses that the Civil Code has given the right to contract existence, creating expectancy to this party about realizing the right he pretends, while the consecutive articles put this fact down. Therefore, it would be more correct that the way of expression by this articles was more clear. So in these provisions somewhere it can be accepted that the insurance contract is a real one, according to Article 1125, but on the other side in the same article it is used the legal term of "suspension" of the insurance contract. A contract which has never existed cannot be dissolved. ${ }^{3}$ This because considering that the insurance contract enters in force at 24 of the day of paying the premium insurance or of its first installment as long as the insured has not paid the insurance premium or its first installment, we are not before e contract dissolution, because this contract is still not engaged, so, it does not exist and an inexistent contract cannot be dissolved. ${ }^{4}$

Even the albanian judicial practice, which has faced this problem and by the request of subjects to interpret these legal cases, has various viewpoints still not unified. In the judicial case of ("Real X L. t. d. against Sigal joint stock company" has two judicial sentences, one of the Judicial District Court of Tirana ${ }^{5}$ and one of the Appeal Court of Tirana ${ }^{6}$, which support the above mentioned interpretation, but there is also a decision, for the same case, of the Civil College of Supreme Court ${ }^{7}$, which has kept a contrary attitude, but declared by the Constitutional Court of the Republic of Albania as unconstitutional for not respecting of due legal process ${ }^{8}$ which is Article 42 of Constitution of Republic of Albania and Article 6 of the European Convention of Human Rights (ECHR). At this point, an insurance contract of goods is entered between the companies "Real X" L. t. d. the plaintiff and "Sigal" J. s. company the defendant. But, according to the practices used before between them, it is accepted that the insurance premium is paid later than the issuance of insurance policy. But when the insurance event happens and there is a damage before the insurance premium is paid by the insured, the parties raise their claims as treated above in consideration of provisions 1124 and 1125 of the Civil Code.

Both courts, that of the first grade and that of appeal keep the evaluation that the insurance contract has never brought any legal consequences for the parties. The insurance contract has never entered in force, because the main condition to enter in the insurance contract is that of paying the premium. The moment of starting the responsibilty of insurer is related to the payment of insurance premium, regardless the fact that the contract is signed, the effects of the contract are conditionally or obligatorily related to premium payment. Moreover, the courts express that since when the insurance contract has been cancelled, up to the moment of premium payment, the moment of certifying the event makes it invalid, because till at this moment Real $X$, the insured, has had all the practical and legal possibilities to pay the insurance premium, but after the event any such possibility is cancelled, because not paying the premium also brings the cancellation of contract releasing the insured from meeting the obligation. Meanwhile, on the other side, the absolute impossibility of paying premium when the event happens, transforms a suspended insurance contract to an invalid contract. ${ }^{9}$

Whereas, the Civil College of Supreme Court, making a re-evaluation of all the case facts, reasons for which, among others the Constitutional Court is hit for illegitimacy holds a contrary attitude. The Civil College provides that the insurance contract

\footnotetext{
1Skrame Olti, Comentary of the Civil Code of Republic of Albania, Second Volume, edition of Onufri, 2011, pg. 655

2 Kondili Valentina, the Civil Law, General Part, edition Maluka, 2007, pg.227

${ }^{3}$ Decision no.269 date 24.05 .2012 of the civil college of the Supreme Court.

${ }^{4}$ Hasneziri. Luan, Contract Insurance according to the Civil Code of Republic of Albania, Doctorate work.

${ }^{5}$ Decision no. 8071 date 29.10 .2010

${ }^{6}$ Decision no.1461 date 21.06.2011

${ }^{7}$ Decision of the Civil College of the Supreme Court no. 269, date 24.05.2012

${ }^{8}$ Decision of Constitutional Court no. 27 date 24.06.2013

${ }_{9}$ Decision of the Civil College of Supreme Court no. 269, date 24.05.2012
} 
was engaged. It holds the attitude that the property insurance contract is a consensual contract and though when the insurance event happened, the insured party has not fulfilled his own obligation (paying premium), for what above argued, the insurer, the defendant party has the obligation to pay to the plaintiff, the insured, the insurance reward within the limit of amount provided in the contract. ${ }^{1}$

In no moment the Civil College explains further the consequences of payment or not of premium by the side of the insured, because the insurer has covered and rewarded the insurance and because the insured has not paid the insurance premium. Would the insured have the right to ask further for the payment of premium by the insured? If so, the insured person could be able to pay even the premium later or not, something not expressed in the Civil Code, being left not arranged as logical result of resolution given by the Civil College to forward this case. Anyway, beyond the reasons, for which Decision no. 269, date 24. 05. 2012 of Civil College of the Supreme Court has been sent to the Constitutional Court, important for this paperwork is the attitude kept from each court.

However, considering the interpretations derived from court decisions we can come to some conclusions. The Civil College evaluates that the insurance contract was in force though the insurance premium was not paid. But, on the other side, this College refers more to the fact that the first instance courts refer to general provisions to resolve the case, the property insurance contract and not to special provisions of the insurance contract of goods during the transport, provided by the Civil Code of Republic of Albania.

Regarding this aspect, considering also the facts of this case the right solution is that the district courts referred to the special provisions about entering in force of the insurance contract for goods during transport since at the begining, according to the principle of "lex specialis, generalis derogate". Therefore, the insurance contract for goods during transport according to article 1148 enters in force at the moment the goods are taken into consignment by the transporter and it ends at the moment of delivery to receiver. Anyway, if we did not have these facts, but a property insurance contract, the interpretation of district courts would be more correct. To my opinion and in context of interpretation of legal provisions of the Civil Code the attention must go to the real and common goal of the contracting parties. The real goal of the parties has been providing insurance of goods by the insurance company, towards premium payment by the insured. The insurance premium payment has never been fulfilled and as a result the suspended contract does not bring any legal consequences for the parties. ${ }^{2}$

In conclusion, except the opinion of some authors that the insurance contract is a real contract, fact to which all the following legal consequences are related, like the entrance in force and the initial of responsibility of the parties, the contractual prediction between the parties is important as well. One of the most important principles in civil law is precisely the will autonomy and the parties must not neglect in this aspect. In lack of clear and understandable provisions in the Civil Code for everyone, in this case it would be more accurate if the parties determine to their will all the cases where they can act to their free will, when the Civil Code itself allows the parties to act through its permissive provisions. If the parties agree with entrance in force of the insurance contract even about paying premium at a later moment, if parties provide this in the contract, to pay the insurance premium, moment which should be clearly determined in the contract, like terms, conditions, installments, after making deal, then the legal situations would be more clear for the parties and therefore the contract becomes a law for them.

Moreover, it would be more correct if legislation made a more accurate definition of the above mentioned issues. For instance, at European level, the European Commission is in process of preparing a Common Framework of references for the European law (European Common Frame of Reference), which refers to the general law of obligations, and especially to the insurance contracts, creating the Principles of European Law for Insurance Contract, principles which apply as second regime, and for which the parties would be free to apply or not in their contractual relationships. ${ }^{3}$

In one of the articles of Principles of European Law of Insurance Contract, it is provided that when the insured makes the payment of the first installment or of all the insurance premium, in order to know if the insurances will be covered by the insurer, these conditions must be indispensably clearly defined in the insurance contract, otherwise they remain effectless

\footnotetext{
1 Ibidem.

2 This case was judged again by the Civil College of the Supreme Court with another judging board, the decision of the civil College of the Supreme Court no. 11117-01956-00-2013 date 16.01.2015 where it reached in exactly aforementioned conclusion.

3 Luik Olavi-Jüri, Kontautas Tomas,Current Issues of Business and Law, 2012
} 
except when: firstly, the conditions have been comunicated to the insured applicant in a understandable language and he must have been asked expressively that in case of non paying the insurance premium he loses the right to be covered with insurance by the insurance company, or secondly, if 2 (two) weeks have passed after taking the communication of such condition, by the insurer, and the insured has not paid the insurance premium yet. ${ }^{1}$ Nevertheless, according to the Principles of European Law of Insurance Contract, the entrance in force of insurance contract is not compulsory after paying the premium. But on the other hand, this provision does not exclude any deal about the effect that paying the insurance premium is a condition of responsibility activation for the insured to cover the insurance and in case such thing is required then it has to be explicitly expressed. ${ }^{2}$

One of the reasons why it is thought that covering with insurance by the insurer should not be done for as long as the insured has not paid the insurance premium is because of fraud and to avoid the fraudulent behaviors. Therefore, in this context it is more reasonable that the insurer does not provide the insurance for all those policeholders who have not paid the premium.

According to the Principles of European Law of Insurance Contract, it is significant that payment of insurance premium is made demandable before the insured event happens, so the last term to pay the insurance premium must be ex ante matured. Otherwise, the insured does not have any obligation to cover the damages. In all these cases, the insurer must have informed the insured about the consequences that come in case of not paying the premium of the insurance contract. In some foreign legislations for example in Latvia it is applied the principle of no premium, no risk...no cover or not paying premium makes the risk not covered. ${ }^{3}$ Whereas unlike our legislation, which gives space to interpretation, there are legislations which have expressively provided such situation. For example, the civil legislation in Latvia provides that an insurance contract enters in force since at the moment when the premium is paid by the insured, for as long as it is not otherwise provided. If the premium is not paid, the contract is considered terminated, if not otherwise provided by the parties. ${ }^{4}$ Exactly here it raises the question if the insurance contract is a real or a consensual contract. But some various authors agree that though an insurance contract would formally be consensual, in many cases and from many legislations it is accepted that in order to consider a contract valid the premium or its first installment must be paid, something that mekas this contract be real. Usually, in the wide practice of insurance contracts in various countries paying the premium is a preliminary condition so that the right to be covered with insurance enters in force, whereas all the other obligations start since at the moment when the contract is considered concluded. ${ }^{5}$ But when the contract will be considered concluded? In this case, it depends on the way how the domestic contract or the contract provides it, if the payment is established as a key contract condition like condition sine qua non for the contract or like an obligation which derives because the contract has already come into force. If the insurance case happens at the moment of making the contract, but before one of premium installments is paid, which is the first installment is paid, the insurer is obliged to pay his obligation. ${ }^{6}$ Even this provisin certifies the fact that the contract has not existed before, but it starts to enter in force after paying the premium or its installments.

Finally, one of the other reasons why the premium or one of its installments must be paid, except the ones mentined above, and avoidance of fraud and abuses by the insured is that the real goal of insurance companies is to cover the risk events with insurance, but being trade companies they intend to realize their profits. Considering the last one, the insurance companies choose or not to insure depending on risks they undertake to insure, like the object to insure, the real circumstances of properties that can be insured, the characteristics of persons who want to be insured in case of life insurance etc. So, one of the goals of insurance companies is to guarantee that the policeholder will pay the premium, because after all it is his essential obligation to keep the insured under insurance cover.

\footnotetext{
${ }^{1}$ Article 5 of Principles for the European Law of Insurance Contract

2 Luik Olavi-Jüri, Kontautas Tomas, Current Issues of Business and Law, 2012

3 Ibidem

$4 \mathrm{lbidem}$.

${ }^{5}$ Luik Olavi-Jüri, Kontautas Tomas,Current Issues of Business and Law, 2012

${ }^{6}$ Ibidem.,
} 


\section{Conclusions}

As widely treated above, we can conclude that according to the above mentioned reasoning, to overviews of other countries legislations, of various authors of law, of attitudes of courts and referring to the general insurance practice, the second paragraph of article 1125 of the Civil Code presents a problem in its meaning and so it is necessary to make an amendment.

Secondly, the insurance contract is a consensual, a legal act for completion of which it is required the expression of the parties' will, regarding the term of the contract, paying premium, the term of paying the premium, the other conditions of the contract, etj. and the consignment of the object in cases of insurance relationship (cash) so paying the insurance premium is made intending the execution of a legal consensual act, because in this case, the consignment of the object is made for the effect of obligation execution. Therefore, the object consignment does not turn the legal act to a real legal one.

Thirdly, the begining moment of insurer's responsibility is related to the payment of insurance premium which is the condition to begin or continue the effective insurance warranty according to the contract signed between the parties implying that despite the fact the contract is signed, the effects of the contract are related to premium payment conditionally and obligatorily.

Fourthly, it is significant that paying the insurance premium has become demandable before that the insurance event happens, so the last term to pay the insurance premium must be ex ante matured. Otherwise, the insurer does not have any obligation to cover the damages. In all these cases, the insurer must have always informed the insured about the consequences that come in case of not paying the premium, in insurance contract.

In conclusion, it is important that in cases when the permissive provisions refer to the autonomy of the parties, the parties have to arrange and provide any possible situation to avoid future conflicts as much as possible.

\section{Bibliography}

[1] Civil Code of Republic of Albania, 1994.

[2] Civil Code of Republic of Albania, of year 1981,

[3] Law no. 52, date 22. 05. 2014 "For the Insurance and Reinsurance activity".

[4] Law no no. 2359 of year 1956 "On legal transactions and obligations"

[5] Law "For Obligatory insurance in transport sector", of year 2009,

[6] Tutulani-Semini Mariana, "The law of obligations and contracts, Special Part" (2006,

[7] Skrame Olti, Comentary of the civil Code of Republic of Albania, second volume, edition Onufri 2011, pg. 655

[8] Kondili Valentina, The Civil Law, general part, editions Maluka, 2007, pg. 227

[9] Nuni A, Mustafaj, I. Vokshi A, The law of liabilities II", Tirana, 2008.

[10] Hasneziri. Luan, The insurance Contract according to the Civil Code of Republic of Albania, Doctorate work.

[11] Luik Olavi-Jüri, Kontautas Tomas, Current Issues of Business and Law, 2012

[12] Sentence no. 8071 date 29. 10. 2010 of Judicial District Court of Tirana

[13] Sentence no. 1461 date 21. 06. 2011 of Court of Appeal of Tirana

[14] Decision of the Civil College of Supreme Court no. 11117-01956-00-2013 date 16. 01. 2015

[15] Decision of the Civli College of the Supreme Court no. 269, date 24. 05. 2012,

[16] Decision of Constitutional Court no. 27 date 24. 06. 2013. 